\title{
A New Methodology to Construct a Database of World University Exams
}

\author{
Jesús María Pinar-Pérez ${ }^{\mathrm{a}}$, Maria Fernandez Moya ${ }^{\mathrm{a}}$, Pedro Cuadros ${ }^{\mathrm{a}}$, Carlos \\ Salvador $^{\text {b }}$, Roberto Morales ${ }^{\text {a }}$ \\ ${ }^{\mathrm{a}}$ University College for Financial Studies, CUNEF (SPAIN), ${ }^{\mathrm{b}}$ Universidad de Valencia (SPAIN)
}

\begin{abstract}
How can we improve the homogenization of university education around the world? This is the central question of our research. In order to answer it, we focus on the classic tool used to evaluate students: exams. The aim of our paper is to establish a methodology with which to construct a database of world university exams by academic field. The database would be available to professors and students worldwide, and both categories could use it to contrast their level in a certain subject. In this sense, our proposal aims to achieve two objectives: 1) to maximize the effectiveness of exams as a measurement of students' knowledge; 2) to use exams as a tool to homogenize education within universities in a certain academic field.
\end{abstract}

Keywords: Homogenization of university education, Exams, quality in university education.

\section{Introduction}

Since the final decades of the 20th century, university education has witnessed rapid growth (for Management Studies see Hutton, 1983; Kipping et al., 2002; Lorbiecki, 1993). However, the quality of the education has varied a lot among the different programs around the world. How can we measure quality in university education? A number of institutions release annual global rankings of universities by to academic fields. One of the most respected lists, the Shanghai Academic Ranking of World Universities, uses a complex methodology to rank world universities, including six objective indicators, i.e. the number of alumni and staff winning Nobel Prizes and Fields Medals, the number of articles published in prestigious journals, the number of Highly Cited Researchers and the number of articles indexed in Science Citation Index - Expanded and Social Sciences Citation Index produced by Web of Science Group, and per capita performance. An overview of the annual list reveals the distance between universities, and offers a picture of global university education as a highly atomized system. 
A special report of the European Parliament (Policy Department B: Structural and cohesion policies, Culture and education) addresses the topic of university quality indicators. The report aims to offer a comparative analysis of the current methods and approaches in Europe in the area of university quality on the one hand, and in the field of rankings on the other, paying special attention to the indicators used in both (see also Cave, 1988; Hattie, 1990; Rowley, 1996). Quality assurance and rankings have different objectives. The main purpose of rankings is to construct a list of the best (Aguillo, 2012). External quality assurance, on the contrary, aims to guarantee compliance with certain standards and enhance quality (see Aerden, 2014; Harvey et al, 1993). The report reflects that "Given the massification and internationalisation of higher education and the increasing competition for talent, the European dimension of quality assurance should be further promoted. This is expected to enhance the performance and attractiveness of European HEIs" (European Parliament, 2015, 75). Today, there are different instruments to improve the quality assurance of higher education, such as the European Standards and Guidelines (ESG), the European Quality Assurance Register (EQAR), international dialogue forums (EQAF), the coordinated collaboration at the European level (ENQA and the E4 group). The study advocates that the international and national projects will be extremely relevant to improving transparency and advancing quality in European higher education (ANECA; Bach et al, 2014; Aerden, 2014; BIS, 2011; Bischof et al., 2014; Blackstock et al., 2013; Bologna process, 2009).

The study of the European Union concludes with seven recommendations on quality assurance (European Parliament, 2015):

1. Further promote the European dimension of quality assurance

2. Support the creation of a quality culture in higher education institutions

3. Facilitate quality assurance approaches responding to the rapidly changing higher education landscape

4. Explore further opportunities for external quality assurance agencies to go beyond measuring compliance with minimum standards alone

5. Cautiously promote the idea of a European quality assurance area

6. Encourage QA agencies to put more emphasis on accessibility and comprehensibility of quality assurance outcomes

7. Support empirical research on impacts of quality assurance

The study suggests that in the current context of higher level education, "it is recommended to support less bureaucratic and more enhancement-oriented approaches attributing primary responsibility for quality assurance to the higher education institutions" (European Parliament, 2015,75). Following the recommendations and the guidelines of the 
aforementioned European Union report, we pose a central question in this paper: How can we improve the homogenization of university education around the world?

\section{Methodology}

To achieve the aim of the paper, the following section (Results) addresses a methodology to build an international database of exams. The database would be available to professors and students worldwide, and both categories could use it to contrast their level in a certain subject, with approved international standards. The criteria and the guidelines are based on our own experience as university professors in a management school. In this sense, our paper is focused on Management Studies, although the findings could be extended to other fields.

\section{Results}

The database of exams aims to standardize international university education. To reach this objective we suggest it be constructed according to the following guidelines:

1. The project could be developed under governmental or EU funds. A group of interdisciplinary scholars from different universities would act as the pioneering group. This group should offer their experience and test the main advantages and challenges of the project. A group of 5 professors (minimum) in each discipline would be necessary to enrich the database with worthwhile material.

2. The basic idea is that each teacher (member of the group) draw up a list of 20 questions, considered key elements in the teaching practice of his/her discipline. These 20 questions should be usual questions formulated in his/her exams, and should cover the complete syllabus.

3. The questions should be 20 multiple choice or true/false questions. The objective of these guidelines is to avoid duplications in professors' lists. It is easier to duplicate questions between members of the group if they are too general. The exam shouldn't include essays, problesms or tasks. We are aware that this is a clear limitation of the project. However, it is important to avoid these open questions to minimize differences among professors' evaluations.

4. Once every professor has proposed a list of questions, the members of the group should check for duplications in the aggregated list. The same topic covered in 
different ways is acceptable, but it would be necessary to eliminate repeated questions.

5. All the professors of the field would examine the aggregated list to check that every topic in the syllabus is addressed. It might be necessary to add further questions to cover potential gaps.

6. The database would be available to all professors of the field and their students (through their respective virtual campuses).

7. The results of the exams should be accessible for both collectives, students and professors. The students would know if they meet the international level in a subject, and the professors could evaluate if they are teaching according to the international standards.

8. A control meeting would be necessary one year after the database was launched. In this potential session, the members of the group would reflect on the positive and negative aspects of the database, and would suggest new ideas to improve its development.

\section{Conclusions}

Following the exhortations and recommendations of European Union report on university education quality assurance, we pose a central question in this paper: How can we improve the homogenization of university education around the world? The answer is to be found in a closer study of the variability in university performance and teaching quality. Accordantly, we focus on the classic tool used to evaluate students: exams. This paper offers a methodology with which to construct a database of world university exams by academic field. The database would be available to professors and students worldwide, and both categories could use it to contrast their level in a certain subject. In this sense, we aim to achieve two objectives: 1) to maximize the effectiveness of exams as a measurement of students' knowledge; 2) to use exams as a tool to homogenize education within universities in a certain academic field.

The implications of the instrument would be relevant for both collectives, especially in a period of globalization, where students and professors continually move from one country to another. The database would enhance the transparency of evaluation systems, and would especially help international students in programs of mobility (such as Erasmus program). 


\section{References}

Aerden, A. (2014). A Guide to Assessing the Quality of Internationalisation. ECA Occasional Paper, The Hague.

Aguillo, I. F. (2012). Rankings de Universidades: El Ranking Web. Higher Learning Research Communications, 2 (1), 3-22.

ANECA [Agencia Nacional de Evaluación de la Calidad y Acreditación], Docentia (Support Programme for Teaching Activity Assessment) - Evaluation Model, [pdf] Agencia Nacional de evaluación de la calidad y acreditación. Retrieved from http://www.aneca.es/eng/Programmes/DOCENTIA

Bach T., Dragojevic, D.et al. (2014). Transparency of European higher education through public quality assurance reports. European Association for Quality Assurance in Higher Education (ENQA), Brussels.

BIS (2011). Higher Education: Students at the Heart of the System. Department for Business, Innovation and Skills, London.

Bischof, L., Gajowniczek, J. et al. (2014). Input Study to the Report from the European Commission on Progress in the Development of Quality Assurance Systems in the various Member States and on Cooperation Activities at European Level. European Union: Brussels.

Blackstock, A. Yung-Chi Hou, C. Moldt, et al. (2013). Internal quality assurance. Assessing impact: Using external reviews and evaluations in internal quality assurance. ENQA Workshop Report 22, Brussels.

Bologna process (2009). The Bologna Process 2020 - The European Higher Education Area in the new decade. Leuven - Louvain-la-Neuve.

Cave, M. (1988). The Use of Performance Indicators in Higher Education, London: Jessica Kingsley.

European Parliament, Policy Department B (2015). Structural and cohesion policies, Culture and education, University quality indicators: a critical assessment, European Parliament Report, 2015. Retrieved from: http://www.europarl.europa.eu/RegData/etudes/STUD/2015/563377/IPOL STU\%282015\%2956 3377 EN.pdf

Hart,. C and Shoolbred M. (1993). Organisational culture, rewards and quality in higher education. Quality Assurance in Higher Education, 1, 22-9.

Harvey, L. and Green D. (1993). Defining quality. Assessment and Evaluation in Higher Education, $18,9-34$.

Hattie, J. (1990). Performance indicators in education. Australian Journal of Education, 34, 249-76, 1990.

Hutton, J. (1983). Management Education for the Changing International Environment. Management Education and Development, 14 (1), 58-67. 
Kipping, M. and Engwall, L. (eds) (2002). Management Consulting: Emergence and Dynamics of a Knowledge Industry. Oxford: Oxford University Press.

Lorbiecki, A. (1993). Unfolding European Management Development. Management Education and Development, 24 (1), 5-13.

Olve, N. (1986). Management Education as a Service Industry. Management Education and Development, 17 (2), 98-110.

Rowley, J. (1996). Measuring Quality in Higher Education. Quality in Higher Education, 2 (3), $237-$ 255. 